\title{
Upaya Revitalisasi Pertanian Rumput Laut Dalam Praktik Pariwisata Di Desa Lembongan, Kabupaten Klungkung
}

I Wayan Gede Wahyu Pradnyana a, 1, Saptono Nugroho a, 2

${ }^{1}$ wahyupradnyana24@gmail.com , ${ }^{2}$ saptono_nugroho@unud.ac.id

a Program Studi Sarjana Destinasi Pariwisata, Fakultas Pariwisata,Universitas Udayana, Jl. Dr. R. Goris, Denpasar, Bali 80232 Indonesia

\section{Abstract}

Lembongan Village is one of the areas that is famous for producing the most seaweed in Nusa Penida Subdistrict, Klungkung Regency. The development of tourism in Nusa Lembongan has led to the increasingly marginalized seaweed farming seen from the decreasing number of farmers and agricultural land switching to the tourism sector. This research is important to be carried out in developing seaweed farming revitalization strategies in tourism practices in Lembongan Village.

The research method used is a qualitative method with qualitative descriptive data analysis techniques. Data sources used are primary and secondary data. Data collection techniques are done by observation, in-depth interviews, and documentation. Determination of the informant is done by purposive sampling procedure.

The results of this study indicate that strategies that can be pursued in the process of revitalizing seaweed farming include; the composition of stakeholders of seaweed farming by three actors, aspects of inhibiting factors and supporting factors of seaweed farming so as to create efforts that can be done to revitalize seaweed farming. Public awareness in the field of seaweed farming should be increased, especially concerns among young people as the next generation

Keyword: Revitalization, Seaweed Agriculture, Tourism Practices

\section{PENDAHULUAN}

Salah satu daerah potensial budidaya rumput laut Bali terletak di Desa Lembongan Kecamatan Nusa Penida, Klungkung yang memiliki kondisi perairan ideal bagi pertumbuhan rumput laut. Kegiatan budidaya rumput laut di Desa Lembongan pernah menjadi primadona yang memberikan pendapatan besar bagi pelaku usaha seperti pembudidaya rumput laut, pengolah dan pemasar.

Saat ini rumput laut berkurang eksistensinya di masyarakat karena terjadi penurunan kualitas panen akibat ancaman dari faktor penyakit dan hama yang mengganggu pertumbuhan rumput laut. Ancaman lainnya bagi keberadaan petani rumput laut yakni perkembangan pariwisata yang berjalan tidak sinergis dalam pemanfaatan wilayah pesisir yang ada di Desa Lembongan berakibat pada meningkatnya alih profesi dari petani menjadi pelaku pariwisata.

$$
\text { Adanya pariwisata yang semakin }
$$
berkembang di Lembongan, membuat masyarakat menjadi silau akan gemerlapnya pariwisata yang menghasilkan uang secara instan dibandingkan dengan membudidayakan rumput laut. Nyatanya pariwisata tidak selalu dapat diandalkan, ada masanya ketika pariwisata menjadi lesu karena tidak adanya daya tarik baru atau jenis kegiatan yang monotone membuat wisatawan merasa jenuh dan bosan. Hal ini menjadi ancaman bagi Lembongan. Masyarakat harus memikirkan cara alternatif untuk mencegah adanya penurunan pendapatan akibat dari ancaman lesunya pariwisata dengan salah satu cara alternatifnya melalui membudidayakan kembali rumput laut yang bersinergi dengan praktik pariwisata.

Rumput laut memiliki potensi untuk bisa dijadikan bagian dalam praktik pariwisata di Lembongan. Hasil olahan dari rumput laut apabila dikembangkan dan dimanajemen dengan optimal kedepannya menjadi produk yang dapat dijual dalam kegiatan praktik pariwisata seperti dikemasnya kegiatan pembudidayaan rumput laut sebagai paket wisata alternatif, menyajikan olahan makanan dari rumput laut, dan souvenir yang mencirikan identitas produk khas Desa Lembongan. Atas dasar tersebut perlu dilakukannya upaya-upaya untuk menggairahkan budidaya rumput laut berkombinasi dengan aktivitas pariwisata. Berdasarkan hal tersebut, fokus artikel ini adalah upaya revitalisasi pertanian rumput laut dalam praktik pariwisata di Desa Lembongan.

Pisau analisis untuk membedah permasalahan pada tulisan ini, yaitu serangkaian konsep dan teori analisis. Konsep dan teori yang digunakan untuk membedah permasalahan, yaitu konsep revitalisasi (Lynch, 1975:6-8) yaitu menyegarkan kembali vitalitas pertanian rumput laut meliputi intervensi fisik, rehabilitasi 
ekonomi, dan revitalisasi sosial; konsep stakeholder (Rahim, 2012:1) untuk mengetahui keterlibatan masyarakat, pengusaha pariwisata, dan pemerintah dalam upaya revitalisasi; konsep praktik pariwisata (Kodhyat, 1983:4) adalah praktik yang saling menguntungkan dimana berhubungan antara wisatawan sebagai guest dengan masyarakat lokal sebagai penyedia fasilitas atau host selama wisatawan tinggal di suatu destinasi; konsep ekowisata (Butcher, 2007:24) digunakan untuk merumuskan daya tarik wisata yang mengandalkan pertanian rumput laut dan bersinergi dengan aktivitas masyarakat; dan teori Tourism Area Life Cycle (Butler, 1980:6) digunakan untuk mengidentifikasi pengembanan pariwisata di Desa Lembongan.

Pada penelitian ini dilakukan penelaahan penelitian sebelumnya untuk membandingkan penelitian yang sudah pernah dilakukan dengan penelitian yang akan dikerjakan. Menelaah penelitian sebelumnya digunakan untuk mengetahui posisi penelitian yang akan dilakukan dengan penelitian sebelumnya serta untuk menjustifikasi kebaruan dalam panelitian ini. Terdapat tiga penelitian sebelumnya terkait fokus dan lokasi penelitian, pertama terkait dengan fokus penelitian Revitalisasi kawasan wisata pesisir Samas, Kabupaten Bantul (Afid Nurkholis, dkk, 2016) dan Model Pengelolaan Wisata Bahari Berkelanjutan Di Pulau Nusa Penida, Kabupaten Klungkung (Darsana, dkk, 2017). Dalam penelitian ini memiliki persamaan fokus membahas mengenai revitalisasi yang akan diberdayakan sebagai daya tarik. Telaah penelitian kedua terkait lokasi, yaitu Problematika Teknis Dan Sosial Ekonomi Usaha Budidaya Rumput Laut Di Nusa Lembongan, Bali (I.W. Arthana, dkk., 2016). Persamaan dalam penelitian ini terletak pada lokasi penelitian yakni di Nusa Lembongan.

Penelitian ini penting dilakukan karena topik pada penelitian ini membantu menyegarkan kembali gairah masyarakat pada vitalitas pertanian rumput laut agar tidak menghilangkan ciri khas dari Desa Lembongan yang pernah berjaya pada masanya. Selain itu peneltian ini penting dilakukan sebagai jalan alternatif untuk membuat suata daya tarik wisata yang dapat bersinergi antara pariwisata dengan pembudidayaan rumput laut. Kebaruan penelitian ini dengan penelitian sebelumnya karena pada penelitian ini akan membahas mengenai upaya-upaya yang dapat dilakukan untuk merevitalisasi pertanian rumput laut dalam praktik pariwisata, dimana akan menjelaskan pemangku kepentingan yang terlibat dalam upaya tersebut.

\section{METODE PENELITIAN}

Penelitian ini mengambil lokasi di Desa Lembongan yang merupakan salah satu desa dari Pulau Lembongan, Kecamatan Nusa Penida, Kabupaten Klungkung, Provinsi Bali. Lama penelitian yang telah peneliti gunakan dalam penelitian ini kurang lebih selama satu bulan pada tahun 2019. Dalam upaya mempertegas batas lingkup permasalahan pada penelitian ini, maka dapat dijabarkan ruang lingkup penelitian sebagai berikut: kondisi eksisting pertanian rumput laut di Desa Lembongan, komposisi stakeholder pertanian rumput laut, faktor pendukung dan penghambat pertanian rumput laut serta upaya revitalisasi pertanian rumput laut.

Jenis data artikel ini adalah data kualitatif dan data kuantitatif (Bungin, 2007). Sumber data dalam penelitan ini meliputi data primer (Moleong, 2005) dan data sekunder (Sugiyono, 2008). Data primer meliputi jumlah petani rumput laut, pendapatan yang dihasilkan dari pertanian rumput laut, level perkembangan destinasi wisata, faktor pendukung dan penghambat pertanian rumput laut dalam perkembangan pariwisata di Lembongan, komposisi stakeholder pertanian rumput laut di Lembongan, serta upaya revitalisasi pertanian rumput laut. Data Sekunder yang dimaksud adalah sejarah, data geografis, data demografis, peta Desa Lembongan.

Teknik pengumpulan data yang digunakan adalah observasi (Bungin, 2007), wawancara mendalam (Kusmayadi, 2000), dan dokumen (Bungin, 2007). Observasi digunakan untuk memperoleh data mengenai kondisi kepariwisataan yang terdapat di Lembongan, kondisi eksisting dari pertanian rumput laut, mengamati pola kegiatan petani rumput laut di Lembongan. Wawancara diaplikasikan untuk menggali data mengenai upaya yang dapat dilakukan untuk revitalisasi pertanian rumput laut dalam praktik pariwisata. Data geografis, data demografis, data pengusaha pariwisata dan dokumentasi foto - foto kegiatan pariwisata serta pertanian rumput laut didapat melalui 
dokumentasi. Teknik analisis data dalam penelitian ini yakni teknik analisis data kualitatif.

\section{III.HASIL DAN PEMBAHASAN}

\section{A. Gambaran Umum Desa Lembongan}

Penelitian ini dilakukan di Desa Lembongan yang secara administratif merupakan bagian dari salah satu dari keseluruhan dua desa yang terdaftar di pulau Nusa Lembongan, Kecamatan Nusa Penida, Kabupaten Klungkung. Nusa Lembongan dan Nusa Ceningan terhubung oleh jembatan berwarna kuning sepanjang 300 meter dengan lebar 3 meter hanya dapat diakses menggunakan sepeda motor, sepeda dan berjalan kaki. Secara administratif Nusa Lembongan memiliki sumber daya manusia berjumlah 4.694 jiwa dengan luas wilayah 837 hektar. Mempunyai kondisi tanah yang tandus gersang dan musim hujan yang melewati bulan Desember sampai Februari dengan intensitas curah hujan rata-rata 1000 mm per tahun membuat Desa Lembongan minim sumber air (Profil Desa Lembongan, 2016). Desa Lembongan memiliki beberapa daya tarik wisata alam dan buatan seperti Pantai Tanjung Sanghyang, Dream Beach, Pantai Devil's Tears, Sunset Beach, Pantai Lebaoh (pantai pusat rumput laut), dan rumah bawah tanah Gala-gala.

Desa Lembongan memiliki ciri khas sebagai daerah penghasil rumput laut dan hasil dari lautnya yang sangat banyak. Pola mata pencaharian penduduk di Nusa Lembongan bisa dikatakan mengalami perubahan yang dinamis sesuai perkembangan jaman. Sebelum masuknya pariwisata ke Nusa Lembongan pada tahun 1991 khususnya Desa Lembongan dengan potensi bahari dan pemanfaatan lahan pertanian rumput laut menjadikan mayoritas mata pencaharian masyarakat sangat terkait dengan sumberdaya laut, khususnya perairan pantai dengan sebagian besar mata pencaharian penduduknya sebagai nelayan penangkap ikan. Namun setelah masuknya pariwisata dan masyarakat mulai mengenal profit dari pariwisata seiring berjalannya waktu pertanian rumput semakin tergeser, kalah saing dengan kemajuan pariwisata.

Pariwisata di Lembongan jika diidentifikasi menggunakan pendekatan Tourism Area Life Cycle (TALC) berada pada tahap pengembangan (development) dimana telah terjadi kunjungan wisatawan dalam jumlah besar dan pemerintah sudah berani mengundang investor nasional atau internatsional untuk menanamkan modal di kawasan wisatawan yang nantinya dikembangkan (Butler, 1980). Melihat perkembangan Lembongan sebagai suatu destinasi pariwisata sejak tahun 1991 berubah begitu massive, pertumbuhan pembangunan penyedia akomodasi bisa dikatakan cepat berkembang bisa dilihat pada tahun 2018 tercatat 94 usaha pariwisata baik itu berupa penginapan, restaurant, spa, speed boat dan hiburan lainnya. Sedangkan Desa Lembongan pada tahun 1990 awal dan tahun 2000an terbilang sedikit memiliki fasilitas akomodasi seperti sekarang. Pemilik perusahaan pariwisata tidak semua berasal dari penduduk lokal, para investor nasional maupun internasional sudah melirik potensi ini dan tengah menanamkan investasinya. Hampir 30\% dari seluruh penyedia akomodasi di Desa Lembongan dimiliki oleh orang luar negeri (investor asing) yang awalnya mereka hanya sebagai wisatawan melihat potensi pariwisata di Lembongan merubah tujuan mereka sehingga membuat suatu perusahaan.

\section{B. Kondisi Eksisting Pertanian Rumput Laut Di Desa Lembongan}

Pada tahun 1984 sampai awal tahun 2000an mayoritas penduduk Desa Lembongan bisa dikatakan hampir $60 \%$ berprofesi sebagai petani rumput laut dengan persebaran wilayah lahan pertanian sebelah selatan pulau Nusa Lembongan sampai Nusa Ceningan. Seiring berjalannya waktu dan keadaan yang berubah secara dinamis pariwisatapun masuk menggantikan posisi pertanian rumput laut yang awalnya menjadi primadona Lembongan, masyarakat yang dulunya sebagai petani mencoba peruntukan di sektor pariwisata guna memenuhi kebutuhan hidupnya. Lambat laun pertanian rumput laut terlihat semakin termarginalisasi karena berkembangnya pariwisata yang begitu massive menggeserkan jumlah dari petani rumput laut yang terdapat di Desa Lembongan. Sempat mengalami penurunan harga jual rumput laut pada tahun 2014, 2015 dan 2016 ditafsirkan pasar rumput laut pada saat itu jebol, sehingga pada tahun 2017 keberadaan petani rumput laut terdata $0 \%$ atau dapat dikatakan tidak ada lagi masyarakat sebagai petani rumput laut. 
Sangat miris melihat perubahan yang begitu kejam dimana pada awalnya mayoritas masyarakat Desa Lembongan membudidayakan rumput laut kini tidak tersisa satupun penerusnya seakan hilang seketika. Namun tidak semua pihak menyerah dengan matinya pertanian rumput laut di Lembongan, masih terdapat beberapa pihak yang menginginkan hidupnya kembali rumput laut. Bapak Wayan Suarbawa salah satunya merupakan masyarakat yang aktif mengampanyekan kembalinya budidaya rumput laut sekaligu sebagai ketua kelompok petani rumput laut di Lembongan yang disebut "Segara Raksa". Kelompok petani rumput laut Segara Raksa ini dulunya berjumlah lebih dari 100 orang namun setelah tahun 2017 kini hanya berjumlah 4 orang petani saja, yakni bapak Suarbawa, bapak Ikun, bapak Kusuma, dan Bapak Juanda .

Adapaun dampak yang relatif ditimbulkan karena hilangnya salah satu profesi utama di Desa Lembongan, seperti meningkatnya angka pengangguran. Hal yang sangat dikhawatirkan apabila suatu saat pariwisata di Lembongan tidak menarik lagi atau bisa dikatakan sepi dari kunjungan wisatawan karena tidak ada pekerjaan lain selain bergelut di dalam praktik pariwisata. Akibat dari adanya penurunan aktivitas pertanian rumput laut tercatat angka pengangguranpun semakin tinggi terutama untuk masyarakat yang berusia diantara 50-60 tahun. Hal yang paling mengkhawatirkan yakni pada regenerasi petani teruntuk pada generasi muda menjadi ancaman dari punahnya pertanian rumput laut karena minimnya minat kerja generasi muda pada sektor pertanian.

Lahan pembudidayaan rumput laut di Desa Lembongan semakin berkurang karena perubahan fungsi lahan pembudidayaan menjadi kepentingan kepariwisataan. Tidak ada yang tahu pasti berapa luas lahan yang dipakai untuk membudidayakan rumput laut pada masa jayanya tahun 1980 hingga awal tahun 2000an namun diperkirakan mencapai 50 hektare dengan ratusan petak lahan yang terisi rumput laut. Sekarang hanya tampak terlihat bekas patok yang dipakai untuk memasang bentangan tali rumput laut, tidak ada lagi pemandangan layaknya sawah di tengah laut seperti dulu. Pemerintah bersama petani mencoba untuk menanam kembali rumput laut sampai pada awal tahun 2019 luas lahan yang dimanfaatkan oleh empat orang petani mencapai 8 are dengan kondisi rumput laut tumbuh dengan subur dimana lahan tersebut tersebar di sebelah selatan Pulau Lembongan berjarak hampir 15 meter dari bibir pantai Lebaoh sebanyak 8 petak. Sementara waktu lahan penjemuran rumput laut berada disalah satu lahan petani milik Pak Juanda yang dulunya memang digunakan sebagai tempat penjemuran.

Pendapatan yang diperoleh dari pertanian rumput laut terbilang besar, dengan intensitas waktu panen 45 hari sekali bisa memperoleh jutaan rupiah tergantung dari berapa banyak petani dapat memanen. Harga rumput laut di Desa Lembongan sendiri untuk saat ini berbeda dengan harga di Denpasar yakni mencapai harga Rp. 20.000 perkilogram untuk rumput laut kering, hal ini dikarenakan jumlah kuantitas atau pasokan rumput laut di Desa Lembongan terbilang sedikit pada tahun 2019. Hasil wawancara beberapa petani yang masih membudidayakan rumput laut mengatakan setidaknya selama 45 hari proses mencapai panen rumput laut kering memperoleh keuntungan kotor Rp.3.000.000 apabila memiliki lahan seluas 1 are dengan berat sekitar 120 150 kilogram. Kondisi ini begitu menguntungkan bagi petani rumput laut yang memiliki profesi utamanya sebagai pengusaha pariwisata sekaligus mempertahankan rumput laut sebagai komoditi utama di Desa Lembongan.

\section{Komposisi Stakeholder Pertanian Rumput Laut}

Pertanian Rumput Laut Lembongan yang kini semakin termarginalisasi perlu diadakan revitaliasi guna mampu bertahan dalam praktik pariwisata, untuk itu perlu adanya sinegritas antara pertanian rumput laut dengan usahausaha pariwisata yang tengah masivve berkembang di Lembongan. Perlunya dukungan dari berbagai pihak yang terlibat diharapkan berperan secara aktif menggalangkan revitalisasi pertanian rumput laut di Lembongan. Bukan hanya petaninya saja sebagai masyarakat yang perlu berjuang namun peran stakeholder lainnya dimana yang dimaksud pemerintah daerah, pengusaha pariwisata, organisasi luar, dan terpenting masyarakat terkait dalam praktik pariwisata sepatutnya mengambil peran agar terjadinya sinergitas antara pertanian dengan praktik pariwisata sehingga menciptakan nilai ekonomis. Adapun stakeholder dalam 
mengupayakan revitalisasi pertanian rumput laut dalam praktik pariwisata diantaranya;

\section{Aktor Masyarakat}

Perkumpulan masyarakat yang berprofesi sebagai petani rumput laut di Desa Lembongan membentuk suatu kelompok tani dinamakan "Segara Raksa" dimana diketuai oleh Wayan Suarbawa dan beranggotakan 3 orang petani. Kegiatan pembudidayaan mulai dilakukan secara intensif dari pemasangan patok besi, pemasangan bentang tali dimana telah dipasang bibit cottoni merah, proses perawatan rumput laut dengan menebar jaring penghalang ikan serta hama berupa rumput liar dan sampai pada tahap penjemuran. Pemberdayaan terhadap petani rumput laut yang ada di Desa Lembongan saat ini dilakukan lebih banyak dari pihak swasta dalam hal ini Lembaga Swadaya Masyarakat dalam bentuk pendampingan. Proses pendampingan ini dilakukan mengingat karakteristik petani rumput laut masih memiliki keterbatasan wawasan dan akses terhadap minimnya informasi. Adapun LSM yang pernah aktif mendampingi Desa Lembongan seperti Satya Posana Nusa yang kerap melakukan penyuluhan mengenai kelestarian lingkungan hidup terutama mengenai ekosistem laut dan pencegahan pembuangan limbah dimana anggota ini terdiri dari 50 orang diambil dari tiap banjar di Desa Lembongan. Organisasi swasta yang juga aktif memperhatikan rumput laut di Desa Lembongan sampai tahun ini yakni Yayasan Kalimajari yang memberdayakan masyarakat petani rumput laut di Desa Lembongan sejak tahun 2005 dengan kegiatan penyuluhan, penggunaan teknologi pertanian rumput laut dan pemasaran produk olahan rumput laut. Kalimanjari melakukan pendampingan kepada masyarakat pesisir dalam pengelolaan sumber daya alam secara berkelanjutan seperti studi atau penelitian, pelatihan, pendampingan program. Proses pendampingan pengolahan rumput laut dari bahan baku pokok sampai menjadi bahan olahan, Kalimanjari telah berhasil mengkemas menjadi beberapa olahan seperti mie dalam kemasan instan, sabun mandi, sirup dan olahan agar-agar. Berikutnya organisasi lain Asosiasi Petani Rumput Laut Indonesia Provinsi Bali dulunya beranggotakan 12 orang dari Nusa Lembongan namun sekarang telah berkurang. Program yang pernah dilaksanakan seperti kepedulian terhadap pertanian rumput laut melalui pengucuran kredit oleh BRI untuk kepentingan media pembudidayaan.

\section{Aktor Pemerintah}

Komposisi stakeholder lainnya dari sisi pemerintah idealnya lebih banyak berperan banyak pada penentuan rambu-rambu dan aturan main secara umum dalam pemberdayaan petani rumput laut. Meminimkan kemungkinan terjadinya sengketa maka diperlukan peran mediasi dan fasilitas kebijakan, terutama dalam menyediakan informasi edukasi pada masyarakat. Dinas Kelautan dan Perikanan Kabupaten Klungkung memberikan bantuan subsidi berupa pemberian benih rumput laut melalui program PUMP. Bupati Kabupaten Klungkung juga sebagai pelopor dalam merevitalisasi pertanian rumput laut sebagai komoditi utama Nusa Lembongan. Perbekel (kepala desa) bersama dinas-dinas terkait mulai bergerak untuk melakukan penyuluhan dan pendataan mengenai minat masyarakat yang ingin membudidayakan rumput laut. Tidak tinggal diam Dinas Ketahanan Pangan dan Perikanan Kabupaten Klungkung memberikan bibit gratis menggunakan dana dari APBD Klungkung tahun 2018 sebagai bentuk motivasi agar masyarakat mau membudidayakan rumput laut seperti dulu.

\section{Aktor Pengusaha pariwisata}

Pengusaha pariwisata disini merupakan stakeholder pendukung dimana statusnya tidak memiliki kaitan kepentingan secara langsung dan terikat terhadap suatu kebijakan dan program, tapi memiliki kepedulian dan berpengaruh seperti misalnya usaha-usaha kecil sampai usaha menengah keatas. Mayoritas masyarakat Desa Lembongan berprofesi dalam bidang pariwisata, mulai dari pegawai sampai dengan pemilik akomodasi. Tercatat selama tahun 2017 terdapat 94 usaha pariwisata yang telah dibangun di Desa Lembongan, dimana usaha penyedia akomodasi seperti hotel, villa, hostel, dan guest house merupakan jenis usaha terbanyak dimiliki oleh masyarakat disusul dengan usaha penyedia makanan seperti restaurant, bar dan warung makan. Pengusaha pariwisata diharapkan menjadi bagian dari stakeholder yang membentuk sinergitas antara pemerintah dan masyarakat dalam pemasaran rumput laut Desa Lembongan. 


\section{Faktor Pendukung Dan Penghambat Pertanian Rumput Laut}

Adapun faktor pendukung dalam upaya revitalisasi pertanian rumput laut diantaranya;

a. Dukungan dari beberapa pihak (stakeholder) terhadap revitalisasi pertanian rumput laut di Desa Lembongan. Keseriusan pemerintah dari tingkat Bupati sampai pemerintah desa menangani permasalahan mengenai keberadaan rumput laut di Desa Lembongan dibantu dengan pendampingan dari lembaga swadaya masyarakat Kalimanjari yang membuat berbagai program untuk merevitalisasi pertanian rumput laut. Melihat keberhasilan dari uji coba penanaman bibit yang menghasilkan rumput laut berkualitas tinggi, kepercayaan masyarakat perlahan mulai tumbuh dan yakin dengan rumput laut bisa dibudidayakan kembali. Pihak pengusaha pariwisatapun mulai melirik ini sebagai potensi untuk memasarkan produk olahan rumput laut sebagai produk oleh-oleh khas Lembongan kepada wisatawan, terdata tiga restaurant dan beberapa Spa akan bekerjasama dengan petani di dampingi Kalimanjari untuk program pemasaran dan pembentukan pasar. Kelompok tani Segara Raksa yang dulunya beranggotakan dua orang kini sudah bertambah jumlahnya menjadi empat orang, walaupun antusias masyarakat yang dulunya sebagai petani sedikit tapi ini menunjukan masih ada harapan dan dukungan dari masyarakat itu sendiri akan keberlangsungan rumput laut di Desa Lembongan.

b. Harga rumput laut melambung tinggi dan meningkatnya permintaan rumput laut kering. Melihat angka permintaan rumput laut yang semakin meningkat setiap tahunnya menjadikan harga rumput laut semakin meningkat dan stabil. Bali pada khususnya mengalami peningkatan nilai jual terhadap rumput laut karena merupakan salah satu daerah yang menghasilkan rumput laut dengan kualitas terbaik di Indonesia. Saat ini nilai jual rumput laut kering meningkat dengan harga Rp.20.000 sampai dengan Rp.30.000 per kilogram tergantung dari kualitas dan permintaan pasar. Berbeda dengan tahun - tahun sebelumnya yang memiliki nilai jual antara Rp. 10.000 sampai Rp.15.000, bahkan pernah anjlok sampai Rp.
2.500 per kilogram. Harga yang meningkat dan stabil menjadi peluang membudidayakan rumput laut, masyarakat harus jeli melihat peluang ini guna meningkatkan taraf kesejahteraan khususnya di Desa Lembongan.

c. Mulai timbul rasa kesadaran masyarakat mengenai keberadaan rumput laut di Desa Lembongan. Bebearapa masyrarakat di Desa Lembongan sudah mulai sadar dengan adanya sektor pariwisata ini secara keberlanjutannya masih diragukan, seperti contohnya pada bencana alam erupsi Gunung Agung yang terjadi pada akhir tahun 2017 lalu menyebabkan sepinya kunjungan dan berimbas pada penurunan pendapatan. Perlunya pilihan alternatif lain selain sektor pariwisata sebagai sumber pendapatan apabila terjadi krisis pada sektor pariwisata, yakni kembali pada pembudidayaan rumput laut. Beberapa masyarakat mulai ikut bergabung dalam kelompok tani Segara Raksa walaupun dalam jumlah yang sedikit tapi sudah membuktikan sebenarnya masyarakat Lembongan masih memiliki kesadaran membudidayakan rumput laut.

d. Pengalaman kerja atau pengetahuan tentang teknik budidaya rumput laut di Desa Lembongan. Jam kerja yang telah dilakukan petani rumput laut di Desa Lembongan terbilang cukup lama, mereka telah mengenal proses pembudidayaan rumput laut sejak tahun 1984 dari awal masuknya rumput laut hingga kini, dari masa jayanya rumput laut sampai hilangnya keberadaan rumput laut. Pengetahuan mengenai rumput laut akan melekat dalam kehidupan mereka dan menjadi suatu kebudayaan, sehingga ketika petani rumput laut sekarang yang melakukan upaya revitalisasi pembudidayaan rumput laut tidak akan lupa bagaimana proses dan tahapan-tahapan mengolah rumput laut mulai dari proses pembibitan sampai pengeringan hasil panen.

Adapun faktor yang menghambat pertanian rumput laut dalam penelitian ini, meliputi:

a. Minimnya minat masyarakat dan kurangnya regenerasi petani di Desa Lembongan. Masyarakat yang dulunya petani mulai beralih profesi menjadi pengusaha pariwisata secara serentak, bagi masyarakat yang memiliki modal mulai membangun penyedia jasa akomodasi dan bagi yang tidak memiliki 
modal maupun keahlian khusus memilih untuk bekerja sebagai pegawai atau setidaknya menyewakan kendaraan. Petani rumput laut dianggap bukan profesi yang menjanjikan untuk memenuhi kebutuhan hidup, perubahan persepsi ini dialami seiring arus modernitas sehingga petani tidak lagi menjadi pilihan utama mereka. Dengan pola hidup mereka yang terbilang hedon karena pengaruh derasnya arus modernitas terutama masuknya kebudayaan luar yang tidak terfilterisasi sehingga tidak disadari mengikuti pola hidup dari wisatawan yang konsumtif. Kalangan remaja berada diposisi nyaman mereka dimana pariwisata dianggap sebagai pilihan paling aman ketika memilih suatu profesi. Krisis regenerasi petani bagi kalangan muda yang enggan terjun ke sektor pertanian menjadi perhatian serius dalam keberlanjutan pertanian rumput laut di Desa Lembongan berbeda dengan bencana yang terjadi secara tiba-tiba dan membawa dampak secara langsung, krisis regenerasi petani berjalan secara pelan-pelan namun membawa dampak yang besar kedepannya tanpa disadari.

b. Kekurangan lahan penjemuran untuk menghasilkan rumput laut kering. Pariwisata yang sedang berkembang di Desa Lembongan membawa dampak yang merugikan bagi keberlangsungan budidaya rumput laut, karena mempersempit ruang gerak petani yang membutuhkan lahan cukup luas untuk aktivitas budidaya rumput laut. Pembangunan penginapan seperti hotel, villa, maupun bungalow terjadi begitu cepat dan menyebabkan berkurangnya lahan budidaya rumput laut di daratan, terutama yang terletak di pinggir pantai mengingat dalam aktivitas budidaya rumput laut membutuhkan lahan yang cukup luas di daratan guna menjemur hasil panen rumput laut agar kandungan airnya berkurang dan siap untuk dipasarkan. Masyarakat yang dulunya sebagai petani enggan kembali bertani dengan alasan mereka kesusahan mencari tempat untuk proses penjemuran, padahal sebenarnya ada beberapa lahan yang bisa dijadikan lahan penjemuran milik petani tanpa biaya sewa.

c. Kekhawatiran dengan terjadinya gagal panen dan jatuhnya harga panen. Kegagalan panen yang sering terjadi pada tahun 2013 sampai tahun 2017 menyebabkan situasi perekonomian pada masa itu menjadi jatuh, harga barang tinggi namun pendapatan menurun. Kegagalan panen yang disebabkan karena hama ikan dan terjadinya pemanasan global secara berkepanjangan menimbulkan berbagai penyakit bagi rumput laut yang hidup di laut. Pada masa krisis tersebut rumput laut memiliki nilai jual yang sangat murah dimana awalnya stabil dengan harga perkilogram Rp.10.000 sampai dengan Rp.15.000 menurun sangat drastis hanya Rp. 3.000 bahkan Rp. 2.500 perkilogramnya. Petani tidak bisa merasakan lagi keuntungan dari rumput laut, banyak tuntutan ekonomi yang perlu dibayarkan sehingga petani meminjam uang kesana kemari berhutang. Atas dasar itulah masyarkat menjadi trauma untuk membudidayakan kembali rumput laut ditambah dengan sedikitnya keberadaan pengepul yang berada di Lembongan.

\section{E. Upaya Revitalisasi Pertanian Rumput Laut}

Adapun upaya revitalisai pertanian rumput laut yang dapat dilakukan oleh stakeholder pertanian rumput laut, adapun tahapannya sebagai berikut:

1. Intervensi Fisik

a. Pemberian bibit gratis rumput laut jenis cottoni merah didatangkan dari Lombok Timur sebanyak 50 kilogram dihibahkan oleh Dinas Ketahanan Pangan dan Perikanan Kabupaten Klungkung kepada kelompok tani Segara Raksa pada tahun 2018. Pemberian bibit ini termasuk dalam program Demontration Plot yang dilakukan sebanyak tiga kali di beberapa wilayah Lembongan pertama kali pada bulan April, bulan Agustus, dan bulan September. Tujuan dari pemberian bibit gratis ini sebagai bentuk keseriusan pemerintah dalam misinya mengembalikan masa kejayaan rumput laut atau merevitalisasi pertanian rumput laut di kecamatan Nusa Penida. Pemberian bibit ini juga sebagai bahan percobanan untuk mengkaji kualitas perairan dan menjawab isu-isu pencemaran laut karena kegiatan pariwisata yang hasilnya bibit dapat tumbuh dengan subur.

b. Program pemurnian bibit diupayakan karena rumput laut terus menerus menurun pada tahun 2015 sampai pada 
tahun 2017 secara nasional karena terjadinya pemanasan global pada tahuntahun tersebut yang menimbulkan matinya rumput laut. Tidak hanya itu penurunan produksi disebabkan menurunnya kualitas bibit rumput laut yang menyebabkan rumput laut tidak dapat tumbuh dengan maksimal sesuai kebutuhan pasar. Bibit yang digunakan sebelumnya di Desa Lembongan merupakan bibit yang telah digunakan berulang-ulang selama proses awal pembudidayaan. Pada akhir tahun 2018 hingga sekarang petani rumput laut menggunakan bibit hasil kulturjaringan sebagai bentuk pemurnian bibit dan memberikan variasi terhadap bibit dengan hasil yang begitu memuaskan dengan berat per ikatnya mencapai 150 gram.

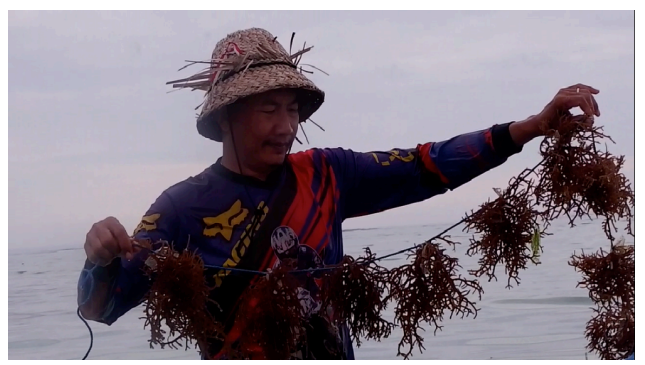

Gambar 1. Penanaman menggunakan bibit kultur jaringan Sumber : Penelitian Lapangan 2019

Penanaman bibit dilakukan secara intensitas waktu tergantung dari proses pengirimin bibit yang diperlukan dan treatment pada bibit rumput laut karena sumber bibit tidak berasal dari daerah Bali. Bibit Kultur jaringan ini didatangkan dari daerah Takalar dengan berat bibit mencapai 50 kilogram yang harga per kilogramnya seharga Rp.75.000 termasuk ongkos kirim. Kedepannya diharapkan melalui program pemurnian bibit akan meningkatkan nilai jual rumput laut tersebut.

c. Menggunakan media baru dalam proses penjemuran rumput laut. Proses penjemuran pasca panen penting diperhatikan mengingat kandungan air yang terdapat dalam rumput laut mempengaruhi mutu dan harga penjualan di pasaran, sering terjadi hasil panen yang bagus tetapi media pengeringan buruk akan mengurangi kualitas rumput laut tersebut karena semakin rendah kandungan air dalam rumput laut semakin mahal nilai jualnya. Media pengeringan rumput laut di Desa Lembongan biasanya menggunakan media penjemuran di atas terpal terpal plastik dibawah teriknya matahari langsung dan rumput laut ditebar secara merata. Penggunaan media ini tidak efisien karena menghasilkan rumput laut berkualitas rendah bercampur pasir dan tanah. Terdapat media alternatif lain untuk mengatasi kekurangan lahan dalam proses penjemuran, salah satunya menggunakan sistim penggantungan yakni hasil panen digantung dengan menggunakan tali pengikat rumput laut yang digunakan untuk budidaya, caranya, saat setelah dilakukan pemanenan rumput laut jangan dilepas dari tali pengikatnya melainkan langsung digantung pada tempat yang telah disediakan seperti pada Gambar 2.

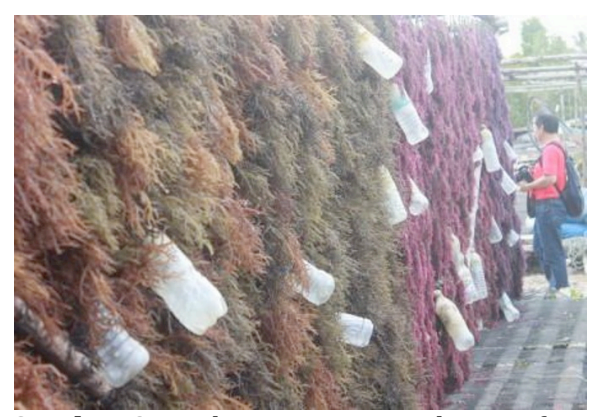

Gambar 2. Media penjemuran alternatif Sumber : Rumputlautindonesia.com

Teknik penjemuran dengan menggantungkan hasil panen bersama tali ris ketika pembibitan pada tiang bambu yang didesain horizontal. Media ini dinilai lebih efisien karena rumput laut tidak mengalami gesekan yang membuat cabang tetap aman dan meminimalkan kandungan air dalam rumput laut. Penggunaan media terpal hanya dianjurkan ketika terjadi hujan atau pada waktu malam hari agar embun tidak mengenai rumput laut.

d. Pembuatan produk olahan rumput laut di Desa Lembongan. Pemerintah memfasilitasi para pelaku industri rumahan dengan tujuan untuk meningkatkan taraf kesejahteraan masyarakat. Pembuatan produk olahan rumput laut di Desa Lembongan di dampingi oleh LSM yayasan Kalimanjari dengan berbagai jenis produk yang nantinya akan dipasarkan dengan target pasar wisatawan yang berkunjung ke Desa Lembongan. Pendampingan dalam pengolahan rumput laut ini sudah dimulai 
sejak tahun 2010 dimana produk pertama yang dibuat adalah jenis makanan dodol rumput laut, selain itu terdapat varian olahan cemilan seperti kerupuk rumput laut dan selai yang diolah oleh ibu-ibu karang taruna beserta petani rumput laut. Kegiatan ini mengalami berbagai kendala, mulai dari teknologi mesin tapi yang paling mempengaruhi terhambatnya produksi karena minimnya ketersedian bahan baku utama yaitu rumput laut dimana pada tahun tersaebut telah hilang keberadaannya yang menyebabkan proses produksi menjadi terhambat. Berkat semangat dari Yayan Kalimanjari di dukung keinginan yang kuat dari masyarakat terciptalah inovasi-inovasi baru dalam pembuatan produk, seperti pembuatan mie, sabun, sirup, lotion, dan scrub seperti pada Gambar 3.

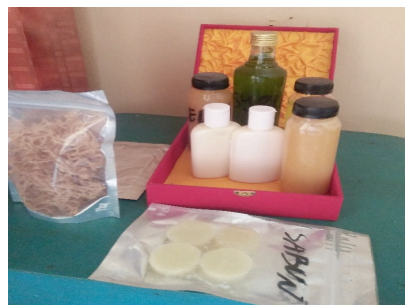

Gambar 3. Produk olahan rumput laut dalam berbagai varian

Sumber : Penelitian Lapangan 2019

Produk-produk baru ini masih pada tahap pengembangan yang artinya masih terdapat banyak kekurangan dalam proses pembuatannya, pengkemasan dan yang paling berat yakni pada proses pemasaran sehingga aktivitas produk berlangsung secara berkelanjutan. Produk ini akan terus berevolusi sampai pada akhirnya menemukan formulasi yang benar-benar cocok dijual dipasaran sehinga memiliki nilai jual yang lebih tinggi.

2. Rehabilitasi Ekonomi

a. Pengemasan produk dalam meningkatkan nilai jual produk olahan rumput laut. Wisatawan yang memilih Lembongan sebagai destinasi tujuannya sering mengalami kebingungan mengenai apakah produk khas dari Lembongan itu sendiri terutama barang apa yang bisa dibawa pulang oleh wisatawan selain barang mainstream seperti kebanyakan di suatu destinasi. Produk olahan rumput laut bisa menjadi kekuatan lokal dan nilai saing dalam menjajagi pasar lokal, sayangnya produk olahan masyarakat kurang bisa bersaing karena pengemasan yang kurang menarik dan minimnya pengetahuan mengenai target pasarnya. Sejauh ini produk rumput laut melakukan pengemasan dengan cara yang sederhana namun itu tidak menjadikan produk terlihat spesial, oleh karena itu upaya mengkemas produk sebagai special gift kepada wisatawan diharapkan akan meningkatkan nilai jual terhadap produk olahan rumput laut.

b. Kolaborasi pengusaha pariwisata dan petani membentuk market. Kalimanjari sebagai lembaga yang mendampingi masyarakat khususnya petani melakukan maping atau pemetaan restaurant pada bulan April tahun 2019 dengan tujuan untuk membentuk kerjasama dengan pihak pengusaha pariwisata di wilayah Desa Lembongan. Pemetaan ini dilakukan dengan harapan menjalin sinergitas antara produk yang dihasilkan dari petani rumput laut dengan pengusaha pariwisata sebagai konsumen sekaligus aktor yang berperan memasarkan produk kepada wisatawan dalam bentuk hidangan makanan. Sejauh ini tercatat tiga restaurant memberikan respon positif mengenai kerjasama yang diajukan, dimana nantinya produk mentahan rumput laut kering akan diolah menjadi salah satu menu makanan mereka, tiga restauran tersebut yakni Sandy Bay restaurant, D'Bias villa \& restaurant, dan L'good. Produk yang nantinya akan dijual kepada konsumen (wisatawan) masih berada pada tahap improvisasi dibagian menu, proses penyempurnaan rasa dilakukan oleh juri masak masing-masing restaurant. Kerjasama dengan tiga restaurant ini merupakan tahap awal dalam meningkatkan eksistensi serta meningkatkan pendapatan petani rumput laut, hal ini bisa dijadikan sebagai batu loncatan untuk membudidayakan kembali pertanian rumput laut dan semakin banyak pihak bekerjasama dalam mengolah produk rumput laut menjadi menu makanan.

c. Pengeluaran izin produk rumah tangga (PIRT). Hambatan yang belum dapat 
terpecahkan dalam perluasan pemasaran produk olahan rumput laut yakni terkendala izin industry rumah tangga dari Badan Pengawas Obat dan Makanan (BPOM). Karena tidak adanya izin dalam mengedarkan produk olahan rumput laut, maka rantai pemasaran hanya berkutat di Nusa Lembongan dan Nusa Ceningan saja. Penjualan industri rumah tangga dalam lingkup Desa Lembongan saja mungkin tidak terlalu berpengaruh apabila suatu makanan tidak menggunakan izin dari BPOM karena sudah tahu bagaimana proses pembuatannya. Melalui Lembaga Swadaya Masyarakat Kalimanjari masyarakat mengajukan untuk dibuatkannya izin ke Dinas Kesehatan dan nantinya dievaluasi serta dinilai oleh BPOM. Adanya PIRT ini berguna untuk meyakinkan kepada konsumen bahwa produk dari olahan rumput laut ini sudah teruji sacara legalitas dan kehigienisan sudah terjamin, jadi konsumen tidak ragu lagi membeli produk ini.

3. Revitalisasi Sosial

Adapun upaya dalam revitalisasi sosial diantaranya;

a. Melakukan kegiatan pelatihan tour guide bagi masyarakat. Sebagai bentuk upaya dalam menumbuhkan kembali minat masyarakat untuk membudidayakan kembali pertanian rumput laut, Yayasan Kalimanjari bersama masyarakat difasilitasi oleh pemerintah Desa Lembongan melakukan suatu kegiatan pelatihan tour guiding. Pelatihan ini bertujuan untuk menarik minat khususnya pada generasi muda melalui pendekatan inovatif diluar dari pendekatan secara konvensional dalam memanfaatkan pertanian rumput laut yang bersinegritas dengan pariwisata. Masyarakat akan lebih mudah tertarik apabila ada unsur nilai ekonomis di dalamnya, pendekatan tradisional seperti melakukan ajakan untuk bertani rumput laut tidak akan efektif karena keinginan masyarakat lebih besar terhadap industri pariwisata.

Pelatihan ini pertama kali berlangsung pada tanggal 8 April 2019 dengan jumlah partisipan sebanyak 20 orang kebanyakan masuk dalam kategori generasi muda yang berdomisili di Desa Lembongan. Sejauh ini terdapat beberapa orang yang sangat tertarik dan serius dalam mengikut pelatihan karena melihat adanya potensi besar dalam mengkombinasikan pertanian rumput laut dengan pariwisata. Selanjutnya pelatihan akan terus dilakukan untuk guna memantapkan materi pada pelatihan sebelumnya.

Segala bentuk kegiatan yang bisa dijual mulai dirancang dan dikemas dengan cara membuat solusi-solusi dari setiap kelemahan yang terdapat di lapangan pada saat itu. Salah satu kelemahan dari pelatihan ini adalah minimya pengetahuan mengenai pembudidayaan rumput laut karena tidak semua peserta pelatihan berlatarbelakang petani, sehingga perlu adanya pembekalan terlebih dahulu. Pengembangan pelatihan ini belum sepenuhnya rampung, masih banyak tahapan yang perlu dibenahi sehingga membentuk suatu paket wisata dan segera diaplikasikan sebagai usaha pariwisata jenis baru.

b. Pemberdayaan petani dalam pengembangan Seaweed tour (ekowisata) di Desa Lembongan dapat meningkatkan kualitas hidup masyarakat petani rumput laut yang berjalan sinergis dengan pelestarian lingkungan, dan budaya bertani. Pemberdayaan petani rumput laut dalam pengembangan ekowisata diharapkan muncul produk pariwisata "bentuk baru" yaitu seaweed tour ekowisata dengan memberdayakan petani rumput laut bersama masyarakat khususnya generasi muda dengan manfaat yang didapat berupa pendidikan dan pembelajaran tentang lingkungan dan mempengaruhi sikap dan perilaku agar peduli terhadap lingkungan. Dalam paket tour ini terdapat keterlibatan dengan tour guide yang berasal dari masyarakat asli Desa Lembongan secara teknis satu orang guide memandu dua sampai lima orang wisatawan. Terdapat pembatasan dalam jumlah wisatawan yang mengambil paket tour perharinya sebanyak 20 orang wisatawan ini bertujuan untuk memberi ruang sirkulasi pada rumput laut serta menjaga kualitas perairan dalam melestarikan ekosistem. Kegiatan dalam paket tour baru dirancang dengan kegiatan seperti melihat proses penanaman rumput 
laut dimana wisatawan diajak turun ke laut untuk memasang rumput laut, snorkling di areal pertanian rumput laut, melihat sunrise melewati jembatan kuning, menjelajahi goa gala-gala dan paket menginap di rumah warga. Tujuan pemberdayaan petani rumput laut dalam pengembangan ekowisata rumput laut merupakan salah satu bagian untuk menarik minat masyarakat untuk bertani kembali serta berimplikasi kepada terjalinnya interaksi harmonis antar sesama petani rumput laut, antar petani dan wisatawan yang berkunjung dan ekosistem alam, sehingga penggunaan atas jasa lingkungan dapat berorientasi jangka panjang.

\section{KESIMPULAN}

Berdasarkan penelitian yang berjudul "Upaya Revitalisasi Pertanian Rumput Laut Dalam Praktik Pariwisata Di Desa Lembongan Kabupaten Klungkung" diperoleh kesimpulan;

1. Kondisi eksistensi rumput laut di Desa Lembongan berdasarkan jumlah masyarakat yag berprofesi sebagai petani rumput laut di Desa Lembongan saat ini berjumlah 4 orang, luas lahan pertanian rumput laut semakin berkurang karena lahan pertanian digunakan untuk kepentingan pariwisata, pendapatan yang dihasilkan dari pertanian rumput laut semakin bertambah dikarenakan nilai jual rumput laut meningkat, dan level perkembangan destinasi wisata Lembongan yang berada pada tahap pengembangan dimana pembangunan akomodasi tengah gencar untuk dibangun.

2. Komposisi stakeholder pertanian rumput laut yang bersinergitas merupakan upaya yang dapat dilakukan untuk merevitalisasi pertanian rumput laut diantaranya aktor masyarakat yang merupakan petani rumput laut berdampingan dengan Lembaga Swadaya Masyarakat, aktor pemerintah mulai dari tingkat daerah sampai tingkat provinsi, dan aktor pengusaha pariwisata di Desa Lembongan.

3. Faktor pendukung dan faktor penghambat pertanian rumput laut membahas mengenai indikator untuk menciptakan upaya yang dapat dilakukan merevitalisasi pertanian rumput laut di Desa Lembongan. Faktor pendukung, yaitu dukungan dari beberapa pihak (stakeholder), meningkatnya harga rumput laut, mulai timbulnya rasa kesadaran masyarakat, serta pengalaman kerja dan pengetahuan mengenai teknik budidaya rumput laut. Faktor penghambat, yaitu minimnya minat masyarakat terutama regenerasi petani, kurangnya lahan penjemuran menghasilkan rumput laut kering, kekhawatiran terjadinya gagal panen.

4. Upaya revitalisasi pertanian rumput laut dalam praktik pariwisata yang dapat dilakukan berdasarkan tahapan intervensi fisik, rehabilitasi ekonomi, dan revitalisasi sosial. Pada intervensi fisik bentuk kegiatan berupa pemberian bibit gratis, program pemurnian bibit, penggunaan media baru dalam proses penjemuran, dan pembuatan produk olahan rumput laut. Pada rehabilitasi ekonomi bentuk kegiatannya berupa melakukan pengemasan produk dalam meningkatkan nilai jual produk olahan rumput laut, kolaborasi pengusaha pariwisata dan petani rumput laut membentuk pasar, dan mangajukan pengeluaran izin produk rumah tangga. Pada revitalisasi sosial bentuk kegiatannya berupa melakukan pelatihan tour guide kepada masyarakat, dan pemberdayaan petani dalam pengembangan seaweed tour.

Sesuai dengan pembahasan dan simpulan akhir dari penelitian ini maka diajukan beberapa saran, diantaranya kepada pihak masyarakat lokal yang berada dalam kegiatan pariwisata di Desa Lembongan maupun tidak, sebaiknya tetap melakukan kegiatan membudidayakan rumput laut sebagai suatu profesi utama, jadikanlah pariwisata sebagai bonus dari keindahan Desa Lembongan. Rumput laut bisa dikemas menjadi suatu daya tarik wisata berbasis ekowisata sebagai bentuk kombinasi antara pariwisata dengan pertanian rumput laut. Masyarakat diharapkan lebih peduli dengan keberadaan pertanian rumput laut terutama pada minimnya minat kalangan muda sebagai generasi penerus petani rumput laut di Lembongan. 
Saran kepada pemerintah tingkat Desa Lembongan selaku payung hukum bagi seluruh lapisan masyarakat desa hendaknya membuat kebijakan khusus mengenai pertanian rumput laut yang perlu ditetapkan untuk membentuk sinergitas antar stakeholder. Pemerintah hendaknya lebih gencar melakukan sosialisasi terhadap masyarakat mengenai pentingnya revitalisasi pertanian rumput laut untuk meningkatkan jumlah petani yang terdapat di Lembongan.

Saran akademis, sebaiknya para akademisi seperti Fakultas Kelautan dan Perikanan dan Fakultas Pariwisata bergandengan untuk melakukan pengabdian masyarakat untuk mengembangkan pertanian rumput laut dan mengkemas produk runput laut menjadi atraksi wisata yang memiliki nilai jual yang lebih tinggi sehingga petani mendapatkan kontribusi ekonomi yang maksimal dari pertanian rumput laut.

\section{DAFTAR PUSTAKA}

Anonim. (2016). Profil Desa Lembongan. Kantor Kepala Desa Lembongan. Klungkung

Arthana, I W., D.B. Wiyanto., I W.G.A. Karang., N.M. Ernawati dan S.A. Saraswati. (2015). Upaya Perbaikan Produktivitas Usaha Budidaya Rumput Laut di Nusa Lembongan, Bali. Seminar Nasional Sains dan teknologi (Senastek), Kuta Bali 29-30 Oktober 2015.
Bungin, Burhan. (2007). Penelitian Kualitatif Komunikasi, Ekonomi, Kebijakan Publik Dan Ilmu Sosial Lainnya. Jakarta: Prenada Media Group

Butcher, J. (2007). Ecotourism, NGO's, and Development: $A$ critical analysis. Buku. Routledge. New York. 208 p.

Butler, R.E. (1980). The Concept of A Tourist Area Cycle Evolution: Implication for Management of Resources. Canadian geographer.

Darsana, I Wayan, dkk. (2017). Model Pengelolaan Wisata Bahari Berkelanjutan Di Pulau Nusa Penida, Kecamatan Nusa Penida Kabupaten Klungkung, Bali. Jurnal Analisis Pariwisata. Vol. 17 No. 1. Universitas Udayana

Kodhyat. (1983). Sejarah Pariwisata Dan Perkembangannya Di Indonesia. Jakarta: PT. Gramedia.

Kusmayadi, et.al. (2000). Metode Penelitian dalam Bidang Kepariwisataan. Jakarta : PT.Gramedia.

Lynch, Kevin. (1975).The Images of The City. The M.I.T Press England.

Moleong, Lexy. (2005). Metodologi Penelitian Kualitatif. Bandung: PT. Remaja Rosdakarya.

Nurkholis, Afis, dkk. (2016). Revitalisasi Kawasan Wisata Pesisir Samas, Kabupaten Bantul. Departemen Geografi Lingkungan, Fakultas Geografi, Universitas Gadjah Mada, Yogyakarta

Rahim, Firmansyah. (2012). Pedoman Kelompok Sadar Wisata. Jakarta: Direktur Jendral Pengembangan Destinasi Pariwisata Kementrian Pariwisata dan Ekonomi Kreatif. Jakarta.

Sugiyono. (2014). Metode Penelitian Kuantitatif Kualitatif dan R\&D. Bandung: Alfabeta 